\title{
Effectiveness of different sanitizers in inactivating $E$. coli 0157:H7 in Tomato and Cucumber
}

\author{
Zohirul Islam ${ }^{1}$, Sabrina Sultana ${ }^{1}$, M. Majibur $\operatorname{Rahman}^{1}$, Sabita R. Rahman ${ }^{1}$, Md. Latiful Bari ${ }^{2,}$ * \\ ${ }^{1}$ Department of Microbiology, University of Dhaka, Dhaka-1000, Bangladesh \\ ${ }^{2}$ Center for Advanced Research in Sciences, University of Dhaka, Dhaka-1000, Bangladesh
}

\author{
Email address: \\ latiful@du.ac.bd (Md. L. Bari)
}

\section{To cite this article:}

Zohirul Islam, Sabrina Sultana, M. Majibur Rahman, Sabita R. Rahman, Md. Latiful Bari. Effectiveness of Different Sanitizers in Inactivating E. Coli O157:H7 in Tomato and Cucumber. Journal of Food and Nutrition Sciences. Special Issue: Food Processing and Food Quality. Vol. 3, No. 1-2, 2015, pp. 60-64. doi: 10.11648/j.jfns.s.2015030102.21

\begin{abstract}
Fresh produce is popular worldwide because it is recognized as an important source of nutrients, vitamins and fiber for humans. However, in the last two decades outbreaks of food borne illness and cases associated with fresh produce have increased significantly. This study was conducted to evaluate the efficacy of acidic electrolyzed water (EO) and alkaline water (AlcO), 200-ppm chlorine water, 3\% $\mathrm{H}_{2} \mathrm{O}_{2}$ and/or sterile distilled water wash in reducing Escherichia coli $\mathrm{O} 157$ : $\mathrm{H} 7$ on the surface of dip-inoculated tomato and cucumber. Inoculated sample (tomato, cucumber) were dipped in $200 \mathrm{ml}$ of electrolyzed acidic or alkali water, or $200 \mathrm{ppm}$ chlorine water, or $3 \% \mathrm{H}_{2} \mathrm{O}_{2}$ and/or sterile distilled water and hand rubbed for 90 seconds followed by second wash with sterile distilled water for 90 seconds to minimize the residual effect. Approximately 2.0 $\log$ CFU/g reduction was observed when washed with acidic electrolyzed water (EO) and alkaline water (AlcO). On the other hand, approximately 3.0-4.0 $\mathrm{log} \mathrm{CFU} / \mathrm{g}$ reduction was observed while washing with chlorine water and $3 \% \mathrm{H}_{2} \mathrm{O}_{2}$. Washing with distilled water found ineffective in reducing the pathogen. Prevalence of total microbial population, coliforms, Salmonella enteriditis, E. coli O157:H7, Listeria monocytogenes, Yersinia enterocolitica was also observed in non-spiked samples (tomato, cucumber). It was found that total microbial population, coliform bacteria and other pathogens varied among different samples depending on the location and type of samples. However, no Salmonella spp., were found in the tested samples. The results revealed that $3 \% \mathrm{H}_{2} \mathrm{O}_{2}$ or 200 ppm chlorine water gave better reduction than that of acidic electrolyzed water and alkali water.
\end{abstract}

Keywords: Fresh Produce, Sanitizers, E. coli O157:H7, and Electrolyzed Water

\section{Introduction}

Fresh fruits and vegetables are an essential part of the diets of people around the world. Nutritionists emphasize the importance of fruits and vegetables in a healthy diet, and researchers have recommended the consumption of at least five servings per day. Possibly as a result of these efforts, over the past decade there has been an increase in the consumption of fresh fruits and vegetables, concurrent with increased global distribution, which has made more varieties of produce available year-round. The US Food and Drug Administration (FDA) conducted several studies to determine the percentages of imported fresh produce contaminated with three pathogens: Escherichia coli O157:H7, Salmonella and Shigella spp (FDA, 2011). The FDA is currently conducting considerable similar research with domestic produce. Several outbreaks of human diseases have been associated with the consumption of fresh fruits and vegetables contaminated with foodborne pathogens, such as E. coli, (1) Listeria monocytogenes (2) and Salmonella (3). Outbreaks of E. coli, L. monocytogenes and Salmonella and Bacillus cereus have been associated to the contaminated raw salad vegetables consumption, raw tomatoes (4) respectively. In developing countries like Bangladesh, agricultural practice of vegetable is quite unhygienic. Here vegetable are produced in open field or in homestead gardens. Sorting of the harvested vegetables in open ground and also washing those vegetables in roadside water source is a common practice in rural area of Bangladesh which is a potential source of microbial contamination. Transportation is another potential reason of contamination. Cross contamination causes from the 
transportation of different types of vegetable from harvested site to local bazaar and to city market altogether in a single vehicle (5). And also vegetables are staked together for sell in vegetable market.

The sanitization of fresh fruits and vegetables plays an important role in the improvement of food quality and microbial safety, because the control of spoilage and pathogenic micro-organisms is critical throughout the production chain of growing, processing, distribution and consumption (6). Several researchers have tested numerous sanitizers for efficacy in reducing or killing pathogenic bacteria, such as E. coli O157:H7, Salmonella spp. and L. monocytogenes, on fresh fruits and vegetables (7). Chlorinated water is the most frequently and widely used disinfectant method for the washing of produce (8). Washing with chlorinated water, however, has a minimal sanitizing effect and results in a microbial reduction of $<2.0$ $\log$ CFU $g$ on fresh fruits and vegetables (9). A variety of other chemicals, including chlorine dioxide $\left(\mathrm{ClO}_{2}\right)$, hydrogen peroxide $\left(\mathrm{H}_{2} \mathrm{O}_{2}\right)$, organic acids, trisodium phosphate, ozone and calcinated calcium solution, have been evaluated for their action against foodborne pathogens on fresh produce (10). Most of these sanitizers, however, are made from the dilution of concentrated solutions or powders, the handling of which involves some risk. More natural and less toxic alternatives are preferable. Moreover, they must be both simple and economical to use. Hence, there is a need for more efficacious and less hazardous sanitizers for suppressing pathogenic microorganisms on fresh fruits and vegetables (11).

Electrolyzed water (EW) is originated from electrolysis of a dilute salt solution $(0.1 \% \mathrm{NaCl})$ passing through an anode and cathode electrodes containing electrolyzing chamber. Acidic electrolyzed water (AC-EW) containing hypochlorous acid and having a low $\mathrm{pH}$ (approx. 2. 7) is produced at the anode. Alkaline electrolyzed water (AKEW) which has a high $\mathrm{pH}$ (approx. 11.6), is produced at the cathode (12). Acidic EW, as a sanitizer has been found to produce significant reductions of various food borne pathogenic micro-organisms (13). It has been successfully used as a sanitizing agent not only in food produce but also in agricultural industries (14). The effectiveness of AC-EW in reducing pathogenic microorganisms on fresh vegetables has been examined by several researchers. It has been found successful when applied to reduce populations of Salmonella typhimurium, E. coli O157:H7, aerobic bacteria, coliforms and B. cereus on lettuce (15), L. monocytogenes on lettuce (16);

In our study, we evaluate the effectiveness of different sanitizer including $200 \mathrm{ppm} \mathrm{Cl}$ water, $\mathrm{EW}, \mathrm{H}_{2} \mathrm{O}_{2}$, and $\mathrm{AK}$ EW that are readily available, in reducing food-borne pathogen in fresh produce. In addition, E. coli O157:H7 inoculated study was also done to compare the effectiveness in reducing the bacterial pathogen on the surfaces of cucumber, spinach and tomatoes.

\section{Materials and Methods}

\subsection{Evaluation of Natural Microbial Content in Sample}

\subsubsection{Sample Collection}

Commercial tomatoes and cucumber, were purchased from Shantinagar market, and used on the day of collection. Each tomato weighed $80.0 \pm 0.5 \mathrm{~g}$, cucumber weighed $110.0 \pm 0.5$ $\mathrm{g}$ and Spinach weighed $30 \mathrm{~g}$. All samples measured by an electric balance (Shimadzu Corporation, Japan). Injured or dirty samples were discarded.

\subsubsection{Medium Used}

Tryptic Soy Agar (TSA) medium was used to see the total bacterial count and other selective medium such as Sorbitol MacConkey (SMAC) agar for Escherichia coli, Chromogenic agar for coliform, Bismuth Sulfite Agar (BSA) for Salmonella, Cefexime Tellurite-Sorbitol MacConkey (CTSMAC) for E. coli O157:H7, Listeria selective agar for Listeria monocytogens and Yersinia selective agar for Yersinia spp., are also used.

\subsubsection{Preparation of the Washing Solutions}

All chemicals used for the preparation of the washing solution were purchased from Wako Pure Chemical Co. Ltd. (Osaka, Japan). Washing solutions were prepared immediately prior to application and used within 30 min after preparation. The chlorine solution was prepared using sodium hypochlorite (Wako Chemical, Japan) solution to distilled water ( $\mathrm{vol} / \mathrm{vol})$, and concentration was adjusted to 200ppm. Distilled water (DW) was also used for experiments. Electrolyzed Acidic \& alkaline water was generated with a model ROX-20TA EO generator \& $(0.1 \%)$ sodium chloride was used. The $\mathrm{pH}$ of acidic water was normally $\leq 2.7 \&$ the $\mathrm{pH}$ of alkaline water was normally $\leq 11.25 .3 \% \mathrm{H}_{2} \mathrm{O}_{2}$, solution was prepared by using $30 \% \mathrm{H}_{2} \mathrm{O}_{2}$.

\subsubsection{Washing Protocol.}

In each experimental condition, $80 \mathrm{~g}$ of tomato, and $110 \mathrm{~g}$ of cucumber was washed separately with $200 \mathrm{~mL}$ of the washing solution in a sterile Ziploc bag. Washing was carried out for $90 \mathrm{~s}$ at room temperature by hand rubbing. After washing, the solution was decanted; a second wash was done with $200 \mathrm{~mL}$ of sterile distilled water to remove the residue of the washing solution. After washing experiment, tomato, and cucumber were placed on a sterile perforated tray in a laminar flow biosafety cabinet for $4 \mathrm{~h}$ at $22 \pm 2^{\circ} \mathrm{C}$ to facilitate drying.

\subsection{Procedure for Inoculation Study}

\subsubsection{Bacterial Test Strains}

Strains of E. coli O157:H7 (CARS-3 isolated from bovine feces), were used in this study. To minimize the growth of microorganisms naturally present on vegetable samples, all the test strains were adapted to grow in tryptic soy broth $(\mathrm{pH}$ 7.3; Oxoid) supplemented with rifampicin $(50 \mu \mathrm{g} / \mathrm{mL})$. Plating on media containing rifampicin greatly minimized interference with colony development by naturally occurring 
microorganisms and facilitate the detection of test pathogen on recovery media. Introduction of drug resistant mutations into test strains previously has been used effectively to detect inoculated bacteria in food products (Inatsu et al., 2003).

\subsubsection{Preparation of Inocula}

E. coli $\mathrm{O} 157: \mathrm{H} 7$ was cultured at $37^{\circ} \mathrm{C}$ in $5 \mathrm{ml}$ of tryptic soy broth (TSB; oxoid) medium supplemented with $50 \mu \mathrm{g} / \mathrm{ml}$ rifampicin (TSB-Rif). Cultures were transferred to TSB-Rif by loop at three successive $24-\mathrm{h}$ intervals immediately before they were used as inocula. Cells were collected by centrifugation $\left(3000 \mathrm{~g}, 10 \mathrm{~min}, 22^{\circ} \mathrm{C}\right)$ and resuspended in $9 \mathrm{~mL}$ of sterile $0.85 \%$ sodium chloride. The inoculum $(9 \mathrm{ml})$ with an initial concentration of approximately $10^{7} \mathrm{CFU} / \mathrm{ml}$ was maintained at $22{ }^{\circ} \mathrm{C} \pm 1{ }^{\circ} \mathrm{C}$ and applied to the tomatoes within 1 hour of preparation.

\subsubsection{Inoculation of Vegetable (Tomato, Cucumber)}

Dip inoculation method was used to inoculate tomato, and cucumber with E. coli O157:H7. Six (6) pieces of each sample (Tomato, Cucumber) were dipped into $2 \mathrm{~L}$ of $E$. coli O157:H7 inoculum in a beaker and mixed gently with a sterile glass rod for $20 \mathrm{~min}$. This process was done inside the laminar flow biosafety cabinet. After the inoculum was decanted, samples were placed on a sterile Ziploc bag for washing experiments and were washed as described above.

\subsection{Microbiological Analysis}

The numbers of viable cells of various microorganisms in tomato under various experimental conditions were evaluated. Tryptic soy agar supplemented with $50 \mu \mathrm{g} / \mathrm{ml}$ rifampicin was used as a nonselective medium for determination of number of viable cells for all the pathogens tested. Samples containing E. coli O157:H7 were surface plated onto Sorbitol MacConkey agar supplemented with cefixime $(0.05 \mathrm{mg} /$ liter $)$
(CT-SMAC) and potassium tellurite $(2.5 \mathrm{mg} / \mathrm{liter})$ (CTselective supplement, Oxoid) and $50 \mu \mathrm{g} / \mathrm{ml}$ rifampicin. All ingredients except CT-selective supplement and rifampicin were combined and sterilized by heating at $121^{\circ} \mathrm{C}$ for $15 \mathrm{~min}$. Supplement and rifampicin were added to the molten agar before pouring the medium into petri plates.

\section{Result and Discussion}

\subsection{Effect of Sanitizer in Resident Microbial Population of Vegetables}

In this study, five different sanitizers and two vegetable samples were used to evaluate the effectiveness of sanitizers in reducing total viable count in tomato and cucumber samples obtained from different market of Dhaka city. The prevalence of resident microorganisms and pathogens and the effectiveness of sanitizer in reducing these bacteria were presented in the Table 1. The high prevalence of total viable bacteria ( $4.5 \log \mathrm{CFU} / \mathrm{g}$ ), coliform bacteria ( $2.3 \log \mathrm{CFU} / \mathrm{g}$ ), and $1.9 \log \mathrm{CFU} / \mathrm{g}$ of E. coli, $3.8 \mathrm{log} \mathrm{CFU} / \mathrm{g}$ of Staphylococcus aureus, $3.8 \mathrm{log} \mathrm{CFU} / \mathrm{g}$ of Listeria spp. and $1.7 \log \mathrm{CFU} / \mathrm{g}$ Yersenia spp was recorded in tomato samples. However, no salmonella and vibrio spp was detected in the tomato samples. Washing with 200ppm chlorine water, electrolyzed acidic and alkaline water or $\mathrm{H}_{2} \mathrm{O}_{2}$ exhibited approximately $2.0 \mathrm{log} \mathrm{CFU} / \mathrm{g}$ of reduction of resident bacteria and on the other hand, complete reduction of coliform, E. coli, Staphylococcus aureus, Listeria spp, Yersenia spp found in tomato samples. Salmonella spp., were not found on the tomato surface before enrichment, but after enrichment its presence was detected. This finding suggested that the fresh tomato samples collected from local markets were heavily contaminated with resistant bacteria and is of special concern for human consumption.

Table 1. Prevalence of pathogens in tomato samples and effect of washing with different sanitizer on pathogenic bacteria.

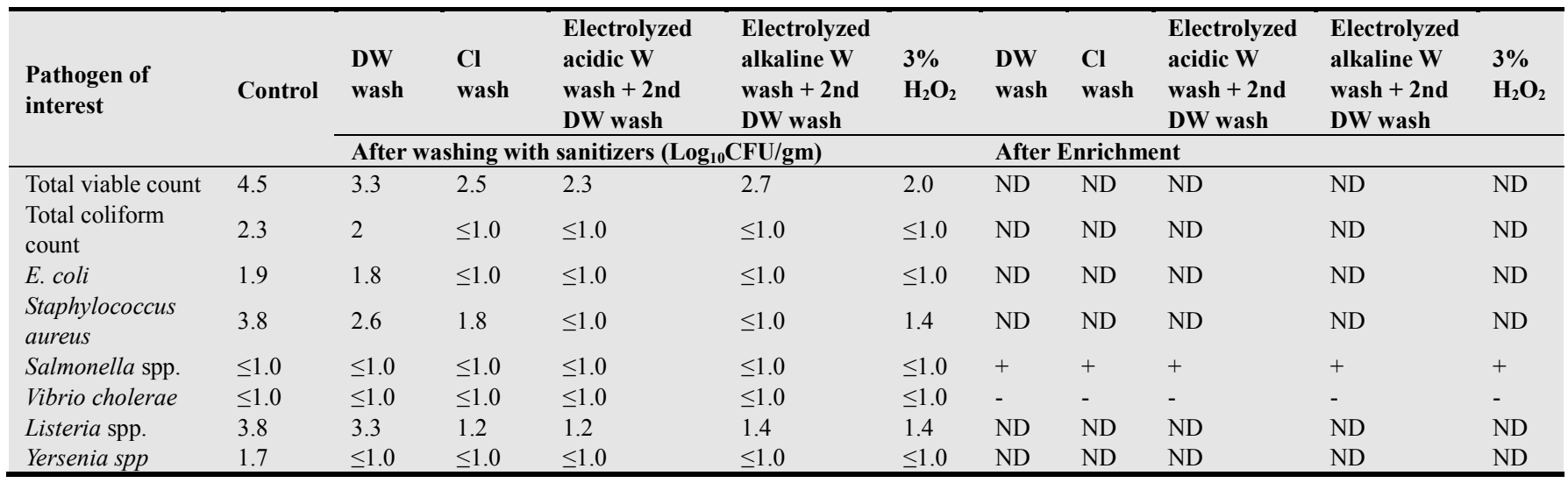

Legend: $\mathrm{DW}=$ Distilled water; $\mathrm{Cl}=$ Chlorine water; $\mathrm{W}=$ Water; Acidic $\mathrm{W}=\mathrm{pH} 2.59$; Alkaline $\mathrm{W}=\mathrm{pH} 11.59 ; \leq 1.0=\mathrm{Below}$ Detection limit. $\mathrm{ND}=\mathrm{Not}$ done as bacterial count was above detectable limit; +=Present; - = Absent.

The cucumber samples was found less contaminated compared to tomato samples. As shown in Table 2, total coliform bacteria, E. coli, E. coli $\mathrm{O} 157$ were found on the cucumber surface before any type of enrichment. After washing with sanitizers the pathogenic bacteria count was almost zero except for distilled water washed samples. However, despite of washing condition, all the pathogenic microorganisms including Staphylococcus aureus, Salmonella spp, Listeria spp showed their presence after enrichment. This finding suggested that enrichment step is a 
must to evaluate the presence of opportunistic pathogen in any food samples.

Table 2. Prevalence of different pathogens in cucumber samples and effect of washing with different sanitizer on pathogenic bacteria.

\begin{tabular}{|c|c|c|c|c|c|c|c|c|c|c|c|}
\hline \multirow[t]{2}{*}{$\begin{array}{l}\text { Pathogen of } \\
\text { interest }\end{array}$} & \multirow[t]{2}{*}{ Control } & $\begin{array}{l}\text { DW } \\
\text { wash }\end{array}$ & $\begin{array}{l}\text { Cl } \\
\text { wash }\end{array}$ & $\begin{array}{l}\text { Electrolyzed } \\
\text { acidic W } \\
\text { wash }+2 \text { nd } \\
\text { DW wash }\end{array}$ & $\begin{array}{l}\text { Electrolyzed } \\
\text { alkaline W } \\
\text { wash }+2 \text { nd } \\
\text { DW wash }\end{array}$ & $\begin{array}{l}3 \% \\
\mathrm{H}_{2} \mathrm{O}_{2}\end{array}$ & $\begin{array}{l}\text { DW } \\
\text { wash }\end{array}$ & $\begin{array}{l}\mathrm{Cl} \\
\text { wash }\end{array}$ & $\begin{array}{l}\text { Electrolyzed } \\
\text { acidic W } \\
\text { wash }+2 \text { nd } \\
\text { DW wash } \\
\end{array}$ & $\begin{array}{l}\text { Electrolyzed } \\
\text { alkaline W } \\
\text { wash }+2 \text { nd } \\
\text { DW wash } \\
\end{array}$ & $\begin{array}{l}3 \% \\
\mathrm{H}_{2} \mathrm{O}_{2}\end{array}$ \\
\hline & & \multicolumn{5}{|c|}{ After washing with sanitizers $\left(\log _{10} \mathrm{CFU} / \mathrm{gm}\right)$} & \multicolumn{5}{|c|}{ After Enrichment } \\
\hline $\begin{array}{l}\text { Total viable } \\
\text { count }\end{array}$ & 5.3 & 4.4 & 2.6 & 3.3 & 3.5 & 3.4 & ND & ND & ND & ND & ND \\
\hline $\begin{array}{l}\text { Total coliform } \\
\text { count }\end{array}$ & 4.5 & 3.6 & 2.4 & 2.8 & 2.7 & 2.6 & ND & ND & ND & ND & ND \\
\hline E. coli & 3.6 & 3.3 & 1.6 & 2.3 & 1.6 & 2.1 & ND & ND & ND & ND & ND \\
\hline E. coli $\mathrm{O} 157$ & 3.0 & 2.6 & $\leq 1.0$ & $\leq 1.0$ & $\leq 1.0$ & $\leq 1.0$ & ND & ND & ND & ND & ND \\
\hline $\begin{array}{l}\text { Staphylococcus } \\
\text { aureus }\end{array}$ & $\leq 1.0$ & $\leq 1.0$ & $\leq 1.0$ & $\leq 1.0$ & $\leq 1.0$ & $\leq 1.0$ & + & + & + & + & + \\
\hline Salmonella spp. & $\leq 1.0$ & $\leq 1.0$ & $\leq 1.0$ & $\leq 1.0$ & $\leq 1.0$ & $\leq 1.0$ & + & + & + & + & + \\
\hline Vibrio cholera & $\leq 1.0$ & $\leq 1.0$ & $\leq 1.0$ & $\leq 1.0$ & $\leq 1.0$ & $\leq 1.0$ & + & + & + & + & + \\
\hline Listeria spp. & $\leq 1.0$ & $\leq 1.0$ & $\leq 1.0$ & $\leq 1.0$ & $\leq 1.0$ & $\leq 1.0$ & + & + & + & + & + \\
\hline $\begin{array}{l}\text { Yersenia } \\
\text { enterocolitica }\end{array}$ & $\leq 1.0$ & $\leq 1.0$ & $\leq 1.0$ & $\leq 1.0$ & $\leq 1.0$ & $\leq 1.0$ & ND & ND & ND & ND & ND \\
\hline
\end{tabular}

Legend: $\mathrm{DW}=$ Distilled water; $\mathrm{Cl}=$ Chlorine water; $\mathrm{W}=$ Water; Acidic $\mathrm{W}=\mathrm{pH} 2.59$; Alkaline $\mathrm{W}=\mathrm{pH} 11.59 ; \leq 1.0=$ Below Detection limit. $\mathrm{ND}=\mathrm{Not}$ done as bacterial count was above detectable limit; +=Present; - =Absent.

As described in methods and materials dipping method had been applied to introduce pathogen (Escherichia coli O157:H7) inoculums on tomato surfaces and effectiveness of the sanitizers (Electrolyzed acidic water, Electrolyzed alkaline water, $\mathrm{H}_{2} \mathrm{O}_{2}$ and chlorinated water) in reduction of experimentally introduced pathogen inoculums were studied. Strain examined was adapted to grow in the presence of $50 \mu \mathrm{g}$ of rifampicin per milliliter, one of several markers used to evaluate the survival of bacterial pathogens in food products with potentially large numbers of interfering background microbiota. Antibiotic-resistant markers have been widely used in studies to determine the fate of pathogens in nonsterile foods, including fresh produce, meats, and milk.

Table 3. Total Escherichia coli O157:H7 count in tomato samples after experimental inoculation and count after sanitizer's treatment.

\begin{tabular}{|c|c|c|c|c|c|c|}
\hline $\begin{array}{l}\text { Medium } \\
\text { used }\end{array}$ & Control & DW wash & $\begin{array}{l}\text { 200ppm } \\
\text { Cl wash }\end{array}$ & $\begin{array}{l}\text { Electrolyzed acidic W wash + } \\
\text { 2nd DW wash }\end{array}$ & $\begin{array}{l}\text { Electrolyzed Alkaline W wash+ 2nd } \\
\text { DW wash }\end{array}$ & $3 \% \mathrm{H}_{2} \mathrm{O}_{2}$ \\
\hline \multicolumn{7}{|c|}{$\log _{10} \mathrm{CFU} / \mathrm{gm}$} \\
\hline TSAR & 4.47 & 3.40 & $\leq 1.0$ & $\leq 1.0$ & $\leq 1.0$ & $\leq 1.0$ \\
\hline \multicolumn{7}{|c|}{ Enrichment } \\
\hline TSAR & ND & + & + & + & + & + \\
\hline SMACR & ND & + & + & + & + & + \\
\hline
\end{tabular}

Legend: $\mathrm{DW}=$ Distilled water; $\mathrm{Cl}=$ Chlorine water; $\mathrm{W}=$ Water; Acidic $\mathrm{W}=\mathrm{pH} 2.59$; Alkaline $\mathrm{W}=\mathrm{pH}$ 11.59; $\mathrm{ND}=\mathrm{Not}$ done as bacterial count was above


Detection limit.

Table 4. Total Escherichia coli O157:H7 count in cucumber samples after experimental inoculation and count after sanitizer's treatment.

\begin{tabular}{|c|c|c|c|c|c|c|}
\hline $\begin{array}{l}\text { Medium } \\
\text { used }\end{array}$ & Control & DW wash & $\begin{array}{l}\text { 200ppm } \\
\text { Cl wash }\end{array}$ & $\begin{array}{l}\text { Electrolyzed acidic W } \\
\text { wash }+2 \text { nd DW wash }\end{array}$ & $\begin{array}{l}\text { Electrolyzed alkaline } W \\
\text { wash }+2 \text { nd DW wash }\end{array}$ & $3 \% \mathrm{H}_{2} \mathrm{O}_{2}$ \\
\hline \multicolumn{7}{|c|}{$\log _{10} \mathrm{CFU} / \mathrm{gm}$} \\
\hline TSAR & 4.5 & 3.2 & $\leq 1.0$ & $\leq 1.0$ & 3.0 & 2.5 \\
\hline $\begin{array}{l}\text { SMACR } \\
\text { Enrichmer }\end{array}$ & 4.0 & 2.2 & $\leq 1.0$ & $\leq 1.0$ & 2.5 & $\leq 1.0$ \\
\hline TSAR & ND & + & + & + & + & + \\
\hline SMACR & ND & + & + & + & + & + \\
\hline
\end{tabular}

Legend: $\mathrm{DW}=$ Distilled water; $\mathrm{Cl}=$ Chlorine water; $\mathrm{W}=$ Water; Acidic $\mathrm{W}=\mathrm{pH} 2.59$; Alkaline $\mathrm{W}=\mathrm{pH} 11.59$; $\mathrm{ND}=$ Not done as bacterial count was above

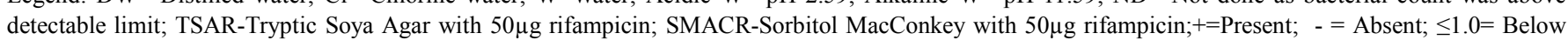
Detection limit.

About $4.5 \log \mathrm{CFU} / \mathrm{g}$ of $E$. coli $\mathrm{O} 157: \mathrm{H} 7$ were recorded in inoculated tomato samples (Table 3). Dipping method was used as this inoculation method was better than any inoculation method used in spiked study. Washing with electrolyzed acidic water, electrolyzed alkaline water,
$3 \% \mathrm{H}_{2} \mathrm{O}_{2}$ and $200 \mathrm{ppm}$ chlorinated water was able to completely reduced the E. coli $\mathrm{O} 157: \mathrm{H} 7$ count compared to non-washed samples, whereas, distilled water wash could reduce only $1.0 \log$ CFU/g compared to non-washed samples. Similar experimental findings were recorded for cucumber 
samples as shown in Table 4. However, after enrichment study, the presence of $E$. coli $\mathrm{O} 157: \mathrm{H} 7$ was detected in all the samples. This finding suggested that sanitizer treatment could able to reduce the bacteria on the surfaces of fresh produce, but were unable to eliminate the bacteria completely.

\section{References}

[1] Abdul-Raouf UM, Beuchat LR, Ammar MS. 1993. Survival and growth of Escherichia coli $\mathrm{O} 157: \mathrm{H} 7$ on salad vegetables. Appl Environ Microbiol 59(7):1999-2006.

[2] Arumugaswami RK, Ali GRR, Abdul-Hamid SNB. 1994. Prevalence of Listeria monocytogenes in foods in Malaysia. Int J Food Microbiol 23:117-21

[3] Al-Hindawi N, Rished R. 1979. Presence and distribution of Salmonella species in some local foods from Baghdad City, Iraq. J Food Prot 42(11):877-80.

[4] Economic Research Service (ERS) U. S. Department of Agriculture. (2007). Food availability data system. http://www.ers.usda.gov/data/foodconsumption/FoodAvailSpr eadsheets.htm viewed November 19, 2007

[5] Mahovic, M., Sargent, S. A., \& Bartz, J. A. (2005). Identifying and controlling postharvest tomato diseases in florida. University of Florida Institute, of Food and Agricultural $\begin{array}{llll}\text { Sciences. } & \text { (UF/IFAS), } & \text { Doc. } & \text { HS }\end{array}$ (http://edis.ifas.ufl.edu/HS131).

[6] Allende, A., Aguayo, E., \& Artes, F. (2004). Microbial and sensory quality of commercial fresh processed red lettuce throughout the production chain and shelf life. International Journal of Food Microbiology, 91,109-117

[7] Beuchat, L. R. (1998). Surface decontamination of fruits and vegetables eaten raw: A review. Food Safety Unit, World Health Organization, WHO/FSF/FOS/98.2.

[8] Beuchat, L. R., Adler, N. B., and Lang, M. M. (2004). Efficacy of chlorine and peroxyacetic acid sanitizer in killing
Listeria monocytogenes on iceberg and Romaine lettuce using simulated commercial processing conditions. J. Food Prot. 67, $1238-1242$.

[9] D'Lima, C. B. and Linton, R. H. (2002). Inactivation of Listeria monocytogenes on lettuce by gaseous and aqueous chlorine dioxide gas and chlorinated water. Abstract 15D-4. IFT 2002 Annual Meeting and Food Expo, Anaheim, CA

[10] Annous, B. A., Sapers, G. M., Mattrazzo, A. M. et al. (2001). Efficacy of washing with a commercial flat-bed brush washer, using conventional and experimental washing agents, in reducing populations of Escherichia coli on artificially inoculated apples. J. Food Prot. 64, 159-163

[11] Lin, C.-M., Moon, S. S., Doyle, M. P. et al. (2002). Inactivation of Escherichia coli O157:H7, Salmonella enterica Serotype Enteritidis, and Listeria monocytogenes by hydrogen peroxide and lactic acid and by hydrogen peroxide with mild heat. J. Food Prot. 65, 1215-1220.

[12] Inatsu, Y., Bari, M. L., and Kawamoto, S. (2007). Application of acidified sodium chlorite prewashing treatment to improve the food hygiene of lightly fermented vegetables. JARQ 41, $17-23$.

[13] Rahman, S.M.E., et al., Effectiveness of low concentration electrolyzed water to inactivate foodborne pathogens under different environmental conditions, International Journal of Food Microbiology (2010), doi:10.1016/j.ijfoodmicro.2010.03.020

[14] Haq M.I Sugiyama J. Isobe S. Applications of Electrolyzed Water in Agriculture \& Food Industries (2005). Food Sci. Technol. Res.,11(2), 135-150

[15] Koseki. S, Yoshida. K, Isobe. S, Itoh. K. 2001. Decontamination of Lettuce Using Acidic Electrolized Water. Journal of Food Protection, Vol.64, No.5, , pages 652-658

[16] Paola Casadiego Laíd, Rocío Cuartas Vivian, Marcela Mercado, Milciades Díaz, Ana Karina Carrascal. Effectiveness of electrolyzed oxidizing water for inactivating Listeria monocytogenes in lettuce Universitas Scientiarum, vol. 10, núm. 1, 2005, pp. 97-108 